\title{
Disciplines for and against Psychology
}

\section{Disciplinas a favor y en contra de la Psicología}

Recibido: febrero 21 de 2011 | Revisado: marzo 24 de 2011 | Aceptado: marzo 28 de 2011

\author{
ERICA BURMAN * \\ Manchester Metropolitan University, Reino Unido
}

\section{A B S T R A C T}

This paper evaluates the scope and functions of interdisciplinary connections for psychologists in dealing with its conceptual and methodological and sometimes political difficulties. Developing examples from my own context and practice, I indicate how feminist research has engaged with and addressed such questions. Brief consideration of three key epistemological turns in psychology, indicates that psychologists should neither uncritically turn to, nor turn away from, other disciplines but rather understand how what it is within such turns that indicates more about the nature of the conceptual, methodological and political problems we are trying to address. Key words author

Critical psychology, epistemological turn, interdisciplinarity, feminist theory. Key words plus

Epistemology, philosophy of psychology, paradigms.

\section{RES U MEN}

Este artículo evalúa el alcance y las funciones de las conexiones interdisciplinarias para el manejo, por parte de los psicólogos, de sus dificultades conceptuales, metodológicas y algunas veces políticas. Desarrollando ejemplos del propio contexto y práctica de la autora, se señala cómo la investigación feminista ha considerado tales cuestiones y se ha involucrado en ellas. Una breve aproximación a los tres giros epistemológicos claves en Psicología, indica que los psicólogos no deberían acríticamente, ni girar hacia ni apartarse de, otras disciplinas, sino, por el contrario, entender cómo lo que hay en cada giro aporta a la naturaleza de los problemas conceptuales, metodológicos y políticos que se intenta abordar.

Palabras clave autor

Psicología crítica, giro epistemológico, interdisciplinariedad, teoría feminista.

Palabras clave descriptores

Epistemología, filosofía de la psicología, paradigmas. 
In this paper I address the ways we 'turn' to other disciplines to help psychology out of its difficulties, difficulties that, as I will argue, are conceptual, methodological and also difficulties of legitimacy. I will propose that we should neither uncritically turn to, nor turn away from, other disciplines; but rather that we need to understand more about the nature of the conceptual, methodological and political problems we are trying to address. These arguments will first be illustrated through three examples drawn from research projects I have been involved with to highlight some of the complicated issues at stake in the relations between disciplines, including when and how they become relevant, and when disciplinary distinctions turn out to be far less important than other issues. The examples will then be used to illustrate my concern here with 'disciplines', addressing the question of disciplines in a double sense: first, in terms of the role of interand trans-disciplinary perspectives in formulating a more engaged, critical and reflexive psychological theory and practice; and in that regard, second, how this attention to relations between disciplines also provides better understanding of how psychology itself functions in disciplinary ways, in terms of generating and supporting a model of subjectivity as reflexive and self-regulating.

In particular, I make a case for the specific role of feminist analyses in countering the damaging effects of psychology, and in helping build alliances and solidarities with other disciplines that do not merely uncritically dissolve psychology into those other disciplines, nor allow for a too simple coexistence across and between disciplines. Indeed it could be argued that feminist perspectives are necessarily 'antipsychological', in the sense of critiquing and exposing the ideological (including ideologies of gender and gender relations) forms and functions of the discipline (see Squire, 1990). While feminist perspectives are not unique in this respect, they do offer a particularly useful critical and analytic lens through which to approach the question of disciplines in relation to psychology. Through this analysis, then, I will claim a place for what we might call 'antipsychology' as a legitimate - and indeed relevant and useful - response to psychology, and for feminist perspectives as a key resource for antipsychological psychologists.

In the final part of the paper, I link this discussion of disciplines to discuss three major 'turns' that have swept across the social and human sciences: the deconstructionist turn, the psychosocial turn, and the neopositivist turn. I will suggest some ways the first two can help us to manage the third. In these postmodern days, these turns are of course neither exactly successive nor even absolutely distinct; however, precisely because of this, we need to be alert to their continuities as well as challenges. So let me start with the practical examples.

\section{Example One: A developmental psychologist in childhood studies}

In its early years (at least in the UK), childhood studies (sometimes known as the 'new sociology of childhood') was very hostile to psychology, which was seen as responsible for a model of the child as deficient, incompetent and generally lacking. ${ }^{1}$ This was in contrast to the 'competent social actor' and rights wielding model of the child that was being formulated from sociology and anthropology (See e.g. James \& Prout, 1990; Jenks, 1996). Here was a direct disciplinary clash, such that - as a critical developmental psychologist, I was regarded with suspicion when I attended at early interdisciplinary events held to discuss and publicise this new research area. However, this hostility could tip into its opposite. Childhood studies soon discovered its own developmental limits and could suddenly become over-deferential to psychology. So my role as a critical (feminist) developmental psychologist, engaged in discussion and dialogue with this emerging hybrid discipline called 'childhood studies', has been both to show that there is sustained

1 This concept derives from psychology's association with and responsibility for stage models of child and individual development in terms of successive shifts of qualitative changes (although of course psychology was only of many disciplines influenced by this structuralist turn). It should be noted that whereas initially such attention to qualitative change was heralded as enabling a more appreciative evaluation of children as different from, rather than lesser or deficient forms of, adults in recent years such attention to developmental limits was seen as exclusionary and oppressive. 
critique within the discipline of psychology (see e.g. Burman, 2008a, 2008b; Henriques, Hollway, Urwin, Venn \& Walkerdine, 1984; Morss, 1996; Walkerdine, 1988), and also to help formulate a more robust framework for theory and practice in childhood studies that does not unthinkingly lapse back into the discourse of stages or competence limits of traditional psychology.

But - to connect with my theme of feminism as an analytic resource - in many countries, the central issue in childhood studies is less disciplinary than pro or antifeminist. Or rather, how the conceptualisations around, and corresponding policy and practice interventions for, children connect with those proposed in relation to women. In the (over)developed world some varieties of childhood studies have been antifeminist - generated as a mistaken response to the ways women and children's interests have been treated as equivalent (and reacted against also by some feminist movements) (Burman, 2008a). Elsewhere, perhaps precisely because of the clarity of ways that women's and children's issues coincide 'on the ground', and in particular as the last sector of the poor to be mobilised for exploitation by multinational capital (Nieuwenhuys, 2007), feminists are very active around children's issues. Of course this des not mean that there are not also significant silences or absences of feminist debate and intervention that reveal the class and cultural backgrounds and collusions of feminist movements too (as Balagopalan, in press, highlights in relation to the Indian feminist movement's failure to challenge the government over early marriage).

I hope the key points I have made so far are obvious: first, that simple disciplinary transfer or replacement often does not solve the problems that prompted such excursions; second, that making alliances across disciplines is very important; and third, that one can be a deconstructionist critic within one's discipline but still a disciplinary representative (as also a resident critic) in others.

\section{Example Two: Disciplines blurred/ psychology in culture - 'Gemma'}

My second example takes the form of a discursive analysis, speaking to the textual turn in psychology, which also situates psychology as a social practice within wider sociopolitical and cultural practices. The text I discuss here is a recent advertisement that appeared in various UK national newspapers and magazines as an advertising campaign to promote recruitment to social work training. In terms of the connection with psychological theory and practice, its 'marketing message' emphasised the personal, rewarding character of social work, with the tagline 'Social work; it's all about people' and including the reward of making a difference by giving her 'a new chance, a new beginning'. In doing so contemporary readers of this text would of course know (here mobilizing their everyday cultural competence, that is central to any analysis) that this focus on personal engagement and sense of efficacy is explicitly being formulated to counter the general received perception of social work (at least as it functions in the UK) as the key state agency involved in assessing and regulating families. In particular social workers are especially central in central in removing children from families who are deemed neglectful or abusive (such that they are also the first professional group to be blamed in cases where children have died). Even though this is an advertisement (rather than a scholarly or 'serious' text), it is important to clarify that it is still worthy of analysis. Indeed (after Goffman, 1979), it is especially because it is an advertisement that it is particularly useful to analyse, since the work of crafting its various textual and textured messages makes it a cultural repository of ideological features.

2 The small print under the illustration reads: 'People can be fascinating mystifying and rewarding. social work is work with people, it's that simple and that complicated. to find about more about training to be a qualified social worker, with a starting salary of at least $£ 13,500$, call for a booklet on 08456046404 or visit www.socialworkandcare.co.uk' The main logo 'Social work' carries the subtitle or tagline 'It's all about people'. 
As with any first stage of analysis, ${ }^{3}$ we need to describe the text. The main text adopts a graphic novel format showing a story. The 'sad little story' announces itself with a general claim (expressed in graffiti-like writing) that 'teenagers are troubled'. But specifically it is about 'Gemma' who is 'not-sosweet sixteen', 'Gemma' is portrayed in various situations of neglect (sitting at the foot of her mother's bed, with her mother unconscious through alcohol misuse) ('mother hands on misery to daughter'), risk (hanging around on the with other girls smoking and wearing short skirts) ('you can see how it could end') and self harming through distress (burning her forearms with cigarettes) ('It's her way of showing she's hurting inside'). Having established the problem, the story is redemptive; describing 'your' interventions to help 'Gemma' to trust again and express her feelings in more constructive ways (Gemma comes to live in your children's home. But old habits die hard. You give her ice cubes. Holding them gives her the same feeling of release. In time it's not only the ice that melts. You help Gemma learn to trust again', ending with an image of a key (a doorkey?) inscribed with the word 'hope'.

In terms of preliminary analysis, we might note that naturalised, psychological 'truths' are offered, in relation to: (1) notions of 'development' (mobilizing understandings of 'adolescence' as a life stage associated with distinct challenges, with the claim "teenagers are troubled"); (2) ideas of prediction/ teleology (with the phrases "you can see how it can end"; "it's a sad little story"); (3) subscribing to the notion that there are cycles of deprivation (as in "mother hands on misery to daughter" and even in relation to models of (individual) addiction "old habits die hard"). These (contestable) 'truths' are posed by an assertive, but unspecified, authorial voice of unquestionable expertise that uses the present tense of general, universal applicability, of timeless truth - as in the claim that "teenagers are troubled" - that blurs or even occludes questions of

3 Fairclough (1989) for example, structures the process of analysis into three stages: description, interpretation and evaluation. See also Parker (1992); Parker et al. (1999), Burman and Parker (1993). causality (so we do not ask: why are they troubled?); it occludes questions of contextuality (where are they troubled?, and how?), and so makes it all seem inevitable. In terms of constitution of audience (interpellation), the text addresses its reader ("you") directly, as supplying the missing paternal/authoritative figure; as the putative social worker, "you" are powerful, and come to the rescue of this failed/ motherless (and, though less explicitly topicalised, fatherless) girl. The trappings of the welfare state are personalised as your possessions ("your foster home"), and it is "your" work that helps and heals ("you help Gemma to trust again"). Moreover, there is a therapeutic narrative of re-socialisation through personal attention and healing; of facilitative care and intimacy as transformative (an ironic juxtaposition with how most people experience social work interventions, sadly).

Some further reflections can be added to this. Firstly, social workers are here portrayed as societal saviours, heroically warding off the apparently almost inevitable repetition (of addiction, self-harm etc.), and importing "hope" and "a new beginning". Secondly, this works to privilege the interventions of an individual to an individual ("you give her ice cubes"; "you help Gemma to trust again").

So two main themes emerge concerning the role of psychological practice, as mobilized and represented in this professional recruitment campaign: firstly, the psychological frameworks bolster an individualisation both at the level of explanations on offer (rather than focusing on societal neglect, material deprivation etc.) and of form of intervention (exemplified by the therapeutic narrative that exonerates "it's her way of showing that she's hurting inside"). This individualisation has other effects (including making individuals responsible - thus fostering mother-blaming, as a particular - and particularly noxious - form of victim-blaming). Moreover the focus on the story of thwarted development ("a sad little story") recapitulates the classic emphasis in psychology on the abnormal/pathological, in terms of how the normal (of psychology, i.e. the normalised, typical subject or unit of development) is produced through its relation with its margins; this focus on the abnormal/pathological is indica- 
tive of psychology's role in adaptation/regulation (see Phoenix, 1987).

So, drawing on the kind of discursive analysis that deconstructionist approaches enable, this example highlights the ways that psychological ideas circulate as culture and are mobilised within the technical claims to expertise of other professions and disciplines, in ways that we, as criticallyengaged psychologists as well as general cultural critics, might want to interrogate and challenge. Moreover, this text - in its visual and discursive features - this campaign works at the level of emotions (of the fear of danger; of the satisfaction of being helpful) rather than explicit prescription, employing the tropes of femininity to connote more general vulnerability through cultural - even filmic-codes (for its blurry graphics, indistinct and metropolitan imagery recalls the genre of thrillers). This appeal to the popular and to feelings can also be understood as part of a wider psychosocial turn that I will discuss later.

\section{Example Three: Gender and violence, resisting psychologisation}

Over the past 10 years I have been involved in four (inter- or multidisciplinary) projects concerned with supporting women experiencing domestic violence, in particular minoritised women - that is, women from minority ethnic, cultural and religious backgrounds-living in the UK. This involvement arose through a rather strange set of connections - that, significantly, were neither disciplinary nor topicrelated $^{4}$. The topics ranged from service provision around attempted suicide and self harm (Burman, Chantler \& Batsleer, 2002; Chantler, Burman \& Batsleer, 2003; Chantler, Burman, Batsleer \& Bashir, 2001); domestic violence support provision for minoritised women (Batsleer et al., 2002; Burman, Smailes \& Chantler, 2004; Chantler, 2006);

4 The term minoritisation is used to highlight how women from minority groups living in the UK acquire such status as the outcome of a relational process, that is, in relation to a majoritised groups, rather than (only) as a feature of their identities (see Burman \& Chantler, 2005; Burman et al., 2004; see also Gupta, 2003).
Pakistani women who become asylum seekers in the $\mathrm{UK}$ by virtue of experiencing domestic violence (Burman, 2010; Siddiqui, Ismail \& Allen, 2008); and identifying and responding to forced marriage (Burman \& Chantler, 2009; Chantler, Gangoli \& Hester, 2009; Gangoli \& Chantler, 2009). I will attempt to indicate the emergent logic for this sequence of topics.

The key point I want to make here is that in these projects, my academic discipline was irrelevant; or rather subordinated to a feminist/activist history. But even more than this, the analysis that emerged from the projects worked to challenge conventional disciplinary demarcations, and especially the three key ways these demarcations function in public and political discourse around violence. Firstly, the work challenged the public/ private boundary, a division that is profoundly gendered, and also one of the key reasons why violence in the home is not typically considered a matter of public concern or intervention (Chantler et al., 2009; Hanmer \& Itzin, 2000). But the disciplinary trajectory of our projects was indicative and indeed educative: it was part of what educated us. From a background of working to document innovative mental health practices for minoritised groups (Burman, Gowrisunkur \& Sangha, 1998; Burman, Walker \& Gowrisunkur, 2003; Gowrisunkur, Burman \& Walker, 2002) we were initially invited to conduct a project on a mental health issue (attempted suicide and self harm). However we identified this as a public order/public health issue - since the reason many of the women we interviewed were attempting suicide or self harming was because they were in abusive relationships (see Burman et al., 2002).

Moreover, second, we also challenged the separation between state and family violence. For our projects provided documentation of how state oppression - in the form of immigration controls enabled the abuse and violence to take place, by trapping women in the violent relationships - as where husbands or partners said 'if you leave me I'll report you to the authorities and you will be deported', so terrorising the woman into staying. We also documented how, apart from culturally- 
specific domestic violence services, commissioners and providers of domestic violence services failed to recognise or acknowledge this additional barrier to accessing domestic violence service support, and so largely maintained the wider victim-blaming models of why women stayed in abusive relationships (Burman \& Chantler, 2005; Burman et al., 2004).

Finally, through this we challenged the classed and racialised discourse structuring understandings of which women are abused, and which men are the abusers, by showing how dominant discourses and practices produce differential structures of visibility and invisibility. This also worked to counter the disproportionate focus on minoritised women, and minority communities who - as usually among the poorest - are also most subject to public scrutiny in the form of having to access public services (if they can - which many cannot because non-citizens have no such 'recourse to public funds), while domestic violence in the middle classes escapes notice (Burman et al., 2004)5.

Thus in these projects we were working across disciplines, to demonstrate the interconnected character of state, cultural, familial and interpersonal practices. This was a feminist antiracist approach that, perhaps, arguably, did not need particular disciplinary expertise (but included social workers, counsellors, lawyers and community development workers). However some kinds of disciplinary knowledge became relevant in the sense of highlighting the need to challenge psychologisation. So, it was important to highlight that the question of provision around attempted suicide and self harm was not, or not only, a mental health problem but rather pointed to other sets of problems that needed to be addressed at the level of public health, public order and state immigration policies. The same went for the tropes around 'cycles of violence' (and other forms of victim-blaming) that domestic violence workers and service managers reached for

5 And so in the contexts we were researching, where poor women who had citizenship status were able to access public services (whereas those who were not could not), in many respects middle class women were the least well provided for (especially as their economic resources usually relied upon the spouse they were attempting to get away from). too easily, and often in racialised ways, to account for why and how certain groups of women seemed to figure within, or alternatively to be absent from, their services. To sum up, my contribution was as someone helping to address wider audiences and support knowledge claims. But I could have been a sociologist or social policy researcher except insofar as I could help to dissect the forms of psychological discourse in culture that underpinned some of the representations of the minoritised domestic violence victim or survivor. ${ }^{6}$ Hence this example shows the necessary intersection between subject disciplines and state power, and this links to the stakes in resisting the neopositivist revival discussed later.

\section{Feminisms as in/discipline}

In highlighting feminist analyses as a significant resource for psychologists I should make clear what I mean by these. I am not talking about simple female supremacism; nor a blurring of femininity and feminism; nor even a transcending of embodied sex/gender relations, as would be implied by prevailing discourses of gender neutrality, which paradoxically typically work to reinstate gender normativity in the name of erasing it (see Smart \& Sevenhuijsen, 1989).

Clearly defining 'feminism' or a 'feminist perspective' is tricky - no longer is it tenable to describe feminist research 'for women, by women, with women', for example, as was the case in the early days of feminist research (e.g. Oakley, 1981; Stanley \& Wise, 1983). This was at a moment of perhaps necessary corrective to malestream models, but only instituting its own exclusions. Now it is generally acknowledged that a gender analysis applies to all social issues - from ecology to economy (and perhaps especially these). So I will follow Lombardo and Verloo's recent proposal of a procedural definition, in suggesting that feminist analyses can be characterised by ongoing struggle around the

6 Indeed the problems of crossing disciplines to publish work such as this can usher in another set of problems, since - as I encountered - expectations about reporting of methodological and theoretical frameworks differ across disciplines even between the social sciences. 
proliferation of contested visions of gender equality and different debates on notions of gender, sex, and relations of domination and subordination' (Lombardo \& Verloo, 2009, p. 110). These struggles are 'ongoing' because of the centrality of focus on change, and because of the necessary and continuous debate between a variety of irreconcilable debates between/within feminist movements (giving rise to what Judith Butler, 1993, has called 'productive antagonism').

So feminist debates span questions of sameness and difference (between men and women, and between women too), and are transformative of all gender norms. Politically, Lombardo and Verloo highlight that discussions can be seen as relating to inclusion via the principle of equality; they reverse prevailing gender norms via principle of difference, and displace them via the principle of transformation. Crucially, these not only characterise models of gender but also how these function in relation to psychology (see Burman, 1998; Squire, 1990).

Feminist critiques of psychology have ranged in strategy, methodology and topic. They span criticisms of prevailing gendered patterning of achievement, (whether underachievement or overachievement, see Francis \& Skelton, 2005; Walkerdine \& The Girls and Mathematics Unit, 1990), of representation in mental health and illness statistics (for depression, or ADHD etc, see Timimi, 2005). They also highlight and critique gendered assumptions functioning at a more abstract level as inscribed within the terms of models of individual development - as in the ways the rational unitary subject of cognitive development reproduces a culturally masculine trajectory from attachment to detachment (Walkerdine, 1988), to the celebration of rational autonomy (qualities whose limits we are now beginning to see in current economic and ecological crises). Even the arrow of time has attracted feminist critique for its abstraction and unilinearity (Kofsky Scholnick, 2000). The shift to a post-industrial, neoliberal order privileges individual skills rather than muscle strength (what Morini, 2007, calls cognitive capitalism), calling for flexible skills rather than manual labour, and includes the emotional skills to be able to adapt and manage one's feelings under such precarious conditions. But far from being displaced, in these new economic times which have both questioned rationality (of the markets) and ushered in this 'knowledge society' psychology seems to be acquiring a new role in the assessment and regulation of subjectivity. Hence we need to be vigilant about its practices as well as its effects, and feminist psychologists are, I would suggest, well placed to highlight the implicit as well as explicit ways oppressive psychological models and assumptions are at work.

Indeed there are fateful continuities as well as tensions between feminist and psychological analyses - particularly in the Anglophone context where the second wave feminism of the 1970s and 1980s of 'the personal is political' made connections between the public and private spheres and legitimated the domain of the emotional (and the move of many feminists and leftwing radicals into therapy, as clients and practitioners). Notwithstanding these connections, especially in the current political context of advanced capitalism, or neoliberalism, there are particular issues around which playing up the antagonism between feminist and psychological analyses can be useful. In particular, they are useful for the analysis of psychologization (the incitement to work on oneself and one's relationships which has become a key feature of neoliberal governmentality) and feminisation (ditto). It helps to have a feminist critique of these, including how feminisation is not feminism and that women have much to worry about in the celebration of supposedly feminine relational and intuitional qualities now entering the business and education arenas under neoliberalism (Burman, 2004, 2006a, 2006b, 2009). These wider cultural-political developments mean that the question of disciplines is paradoxically both more and less relevant. So now I will turn to address why the question of 'discipline' is crucial both to psychology and to critiques of psychology.

\section{Turning to disciplines}

There is a great deal of talk in the literature calling for interdisciplinary and transdisciplinary approaches - especially in research aiming to be 
socially engaged and anti-oppressive (if not emancipatory). Hence in a significant position paper Denzin (2006) call for a 'methodology of the heart, a prophetic feminist postpragmatism that embraces an ethic of truth grounded in love, care, hope and forgiveness' (p. 770) as a counter current revivals of 'methodological fundamentalism'. Central to these discussions are calls for the celebration of paradigm proliferation as a means of prompting the project of 'coloring epistemologies' (or highlighting the diversity of cultural tools and tracing through their political consequences) to ward off the perpetuation of conservative, malestream dynamics (see Guba \& Lincoln, 2005; Lather, 2006).

Now psychology, as a discipline, has some trouble maintaining itself as distinct. Although we may make much of psychology's claims to be special as a profession with a specific practice as well as a subject area (unlike sociology, for example), its notions of function and unit of analysis are always vulnerable to being defined by other disciplines. Writing of the inception of the 'psy complex', Rose (1985) argued that psychological analysis has always tended to resolve into the medical, due to the lack of clarity over what would count as good functioning, and indeed what functions to count (unlike, say, those functions doctors could draw upon in describing the health or disease of a specific organ). Indeed, it is likely that our preoccupation in psychology with method betrays a core uncertainty and anxiety about the viability of any such attempts to generate meaningful psychological measurements (Michell, 1997, 2004; Trendler, 2009). As Chamberlain (2000) notes, this preoccupation with methodology has also tended to migrate into qualitative research, sometimes at the expense of the ethical-political aims inspiring it in the first place (see also Burman $\&$ Whelan, in press). In Britain, psychology is now officially a 'health profession', and psychologists together with nurses and speech therapists and art therapists (for example) - must be registered under a 'health professions council'.

But if it has trouble maintaining a distinct disciplinary identity, on the other hand, psychology clearly is part of the machinery of disciplining subjects. That is, it is part of the culture of modernity that capitalism has produced, requiring sovereign citizens who are reflexive and self-regulating in the act of choosing, consuming and engaging with the market (Fendler, 2001). Psychologization, the incitement to work on oneself and one's relationships, has become a key feature of neoliberal governmentality (De Vos, 2009, in press; De Vos \& Gordo Lopez, 2010), especially in the post-industrial economic transition to a knowledge-society that privileges relational skills and emotional literacy (Popkewitz \& Bloch, 2001). This has corresponded to a so-called feminisation of work, that for most people extends the insecurity and low pay of women's traditional working conditions to men, so instigating new forms of oppression that far outweigh the few successful women who have made it through the 'glass ceiling'. The corollary of this in the global South includes how gender mainstreaming and tactical engagements with UNDP and World Bank initiatives have worked to reconfigure women's traditional work into entrepreneurial activity ripe for investment via microcredit schemes (Batliwala \& Dhanraj, 2007; Pearson, 2007).

Hence psychologisation and feminisation are fatefully intertwined in their explicit focus on instrumentalising the domain of the personal (including the home, the domestic and relational qualities). Both are linked to histories of individualism and the sedimentation of newer practices of individualisation that work to separate people from each other, and prevent wider reflection on the conditions producing such subjectivities. So, while in some ways women's work has perhaps always stood outside the domain of patriarchal capitalist production (Staples, 2007), its affective features as well as temporal and cultural capital are being colonised into global capitalism. As a correlate of the contraction of public sensibility and engagement under neoliberalism, there has been an expansion of the psychological domain (in true voluntarist mode) from specialist expertise to 'self-help'. We are currently surrounded by incitements to grow, learn, change yourself, make yourself better. In sum, to develop and demonstrate the flexibility and determination to optimise oneself (or what Fendler, 2001, termed 'developmentality'). 
I would also describe my disciplinary background as also based in women's studies, an arena about which there is at least as much discussion about disciplinary identity, viability, distinctiveness as any other (see eg Buikema \& Smelik, 1993; Richardson \& Robinson, 1993). This discussion is highly charged theoretically, and politically; involving such questions as: what is a 'woman' - and is this viable as a general term, abstracted from 'race', class, culture? (Bhavnani, 2001; Riley, 1988; Spelman, 1990). And, in particular, what is at stake in the general shift (that we have seen in the UK, at least) from women's studies to gender studies, or gender relations or even sexuality studies, for example? Leaving these complex questions aside, for now I want to note that - notwithstanding its necessarily trans- and inter-disciplinary character, the question of disciplinary orientation still arises in women's studies (or gender studies or feminist studies, or whatever we might now want to call it). The epistemological project within women's studies may be general, in terms of posing such questions as 'who is a knower?', 'what counts as knowledge?', 'what does it mean for a women to be the subject (rather than object) of knowledgegeneration practices?' (Harding, 1990; Stanley, 1990). However, crucially, these questions assume different forms within different disciplines.

I discovered this when team teaching with a colleague who had a humanities and literature background. We had to translate what these general epistemological and ontological questions meant across the social and human sciences, as they took different form in each. This is especially relevant when we think about the social sciences' and especially psychology's preoccupation with 'method' and 'methodology' (and there is good reason to think that psychology's obsession with this works as some kind of defensive strategy, covering over some essential lack at its core, Trendler, 2009). For in the humanities and literature, theory is method. And there is a key lesson for us here in the social sciences, and in psychology in particular; one that feminists have been highlighting for a long while, and qualitative researchers also have acknowledged: theory and method are necessarily inter-related; so while a specific method may not be specified by a particular theory, each theory invites more and less compatible methodological frameworks according to which its questions can be addressed.

\section{II: Three turns}

Having outlined the problematic of disciplines and some examples of the need to draw upon but also problematise cross-disciplinary relations, I will now move to discuss three theoretical turns that have structured much of the debate and discussion in social theory and practice, including in psychology.

\section{Deconstruction: The turn to the text}

A strategy taken up by feminist and other critics of psychology has been to take psychology's claims and treat them as culturally-formulated and situated text (see also Burman et al., 1995; Burman et al., 1996; Parker, 2007; Parker \& The Bolton Discourse Network, 1999; Parker \& Shotter, 1990; Richards, 1996. This involves locating psychological phenomena in their historical, cultural and geographical contexts, with an attention to how these contexts structure and nuance these phenomena differently. For this, we need to refer to other disciplines - history, sociology, anthropology, for example - to highlight how what is typically claimed to be a stable, general, even timeless and universal phenomenon has arisen at a very particular time and place; and - adding in some political analysis - to serve a very particular set of social agendas (e.g. Rose, 1985, 1989).

For constructionists, including most people working in the humanities or even other social scientists, it is easy to underestimate how disturbing these moves can be for psychologists. Treating mainstream psychological theory and practice as text disrupts its scientism and naïve realist claims, and facilitates attention to how the knowledge, 'facts', norms and models are the outcome of specific contextual productions and interactions. At least eight features about this strategy contribute to a critical psychological practice: 
1. The cultural-historical situatedness of the emergence of particular forms of knowledge and practice is emphasised (as a specific challenge to the timelessness of scientistic psychology).

2. The particular disciplinary practice of psychology is embedded within wider contexts and so disrupts its specialist claims.

3. The high/low culture binary of expert vs. popular/layperson is deconstructed, also highlighting the circularity of underlying conceptual models, cultural assumptions and political preoccupations

4. The avowed position of psychology as neutral, value-free, detached etc, is thereby undermined including also how

5. The authority of the psychologist (or other 'expert') is challenged

6. The role of the theorist/story-teller in their theory/story is highlighted, so

7. ... rendering their account more contestable

8. Inciting attention to the production of attributions of knowledge about, or to, people, including destabilising claims to 'give voice' to research participants - in particular those who have previously been marginalised - such as children or minority groups (Alldred \& Burman, 2005; Jackson \& Mazzei, 2009).

Further, this concern with the practices and tactics of psychologisation also affords a warrant for some methodological latitude in selection of materials for analysis. The proliferation and saturation of the domain of the 'psychological' means that relevant materials surround us. In particular, it brings into focus the everyday ways psychological ideas circulate, rather than being confined to specialist policy or technical journals (although these are also of course important - even if their audiences are rather more restricted). Like banal nationalism and racism (Billig, 1995; Burman, 2010), banal psychologism and its corollaries should exercise our attention, rather than being overlooked or excused as mere 'pop psy'. (Hence my analysis of a social work advertising campaign earlier.)

But there are, of course, problems with deconstructionist strategy as a critical tool. I will high- light just three here. Firstly, there is a tendency to reproduce what they critique precisely by virtue of articulating this critique, rhetorically maintaining the entity under interrogation even through critiquing it (Burman \& Maclure, in press; Elam, 1994). Second, as Foucault (1977) argued, those varieties of work that aim to improve or correct dominant models tend towards a reformism that underestimates the depth of the problems with prevailing paradigms (as was indicated in the flurry of 'reconstructing' psychology texts in the Anglophone literature of the 1970s, e.g. Armistead, 1974, which proved to be premature in terms of presuming the end of the discipline they critiqued). Third, these approaches are also subject to the postcolonial criticism that they function at a level of abstraction from contexts of practice such that they both overstate their difference from and also ignore the varieties, instabilities and contradictions of their reception and enactment within local practices (see e.g. Kothari, 2005).

Returning to the role of feminist analyses we should note that, theoretically and methodologically, feminist analysis is both constructionist and deconstructionist; modernist and postmodernist. Its project of envisioning social change presupposes a relativism in order to conceptualise that things have been and could be different, alongside a practical-political engagement to realise such changes (and in that sense prefigure a different teleology). As Lombardo and Verloo note: 'The feminist combination of constructionist and deconstructionist approaches feeds the ongoing struggle that enables the continuous generation of different partial, sometimes conflicting, positions in feminist debates; these keep the movement and its practices alive, and up to newly emerging challenges and opportunities' (2009, pp. 110-111).

\section{The psychosocial: The turn to affect}

Emotions, or 'affects', feature significantly in current political and academic agendas. Whether as critique of scientistic objectivity (Hollway, 1989), or as a reflexive grounding practice in social science analysis, emotions are increasingly being mobilised, 
textualised and discussed (see e.g. Clough, 2007; Tamboukou, 2003). As incitement to confess or to resist (or both of these), this turn poses new challenges for critical psychologists. While it owes much to the strategies and impact of feminist critiques, this academic interest has emerged alongside and in part to analyse, the intensification of practices of psychologisation and individualisation that exemplify the neoliberal project: of instrumentalization and maximization of hitherto untapped human resources (De Vos, 2009, in press; De Vos \& Gordo Lopez, 2010; Rose, 1989). As I have already indicated, these contemporary practices of (what might be called) emotionalisation range from the psychic flexibility to deal with insecure conditions, to the injunction to keep working on one's development to fit the shifting demands of the labour market (Fendler, 2001; Morini, 2007). This emotionalisation includes attention to the 'irrationality' of the Euro-US markets that produced the downward spiral of the market crash and the implosion of the banks in late 2008, with significant connections to that other affective economy of global insecurity that generates the spurious but potent links between 'immigrant' and 'terrorist', for (a key) example (Ahmed, 2004).

Moreover in terms of shifting gender relations, as the World Bank and IMF turn to women and children's work as a final untapped economic resource (Nieuwenhuys, 2007), it is stereotypically feminine relational skills that are acquiring new value in post-industrial, service-sector based economies (Gordo Lopez \& Burman, 2004). Thus the labour which turned the wheels of industrial modernity, the traditional physical labour of the working class with its values of hard work, physical strength and reliability is now displaced and de-skilled in the neoliberal economy, along with the traditional modes of racialised and classed masculinity associated with this. Within UK social policy, for example, the incitement to intervention has correspondingly shifted to problematise men's health and mental health, with men's physical and psychological vulnerability (with countless undiagnosed medical and mental health difficulties - from diabetes to depression) now a key policy focus. Perhaps it is no accident that it is now men's problematic emotions that are the subject of concern. From 'knife crime' to 'road rage', the gendered expression of anger wrought of dispossession and alienation can now be cast as an individual skills deficit.

In the UK a new (version of an old) discipline is being formed called 'psychosocial studies'. This moves beyond (but probably also owes something to) the discourse of psychosocial interventions in relation to humanitarian emergencies - which for some time have recognised the 'psycho' in the 'social' as well as the scientific-technological aspects of aid. Given the enthusiasm with which psychosocial studies has been taken up in the UK academy (Clarke \& Hoggett, 2009; Frosh, 2010), it is relevant to connect this 'affective turn' with similar shifts in psychotherapy. In the early years of the twenty first century, 'emotional literacy' was actively promoted by some educators and therapists despite its nakedly commercial and cognitive origins (in the notion of 'emotional intelligence'). Psychotherapists allied with policy makers of the new labour strategy of 'social inclusion', hoping that the broader project of the promotion of emotional well-being could be connected with this (e.g. Orbach, 2001).

While we have yet to see how therapists will respond to the new British coalition government discourse of the "big society" (although the current vogue for 'mindfulness' and 'mentalisation' approaches have been anticipating such moves for some time), the linking of goals for individual and social change leads to some obvious problems. Such examples clarify how a more emotionally sensitive agenda is not necessarily any less signed up to capitalizing on emotions than a cognitivist one, for psychoanalytic practitioners (such as Bowlby \& Winnicott) were from the beginning keen to bring the good news for management and government (Riley, 1983). In the name of promoting 'social inclusion', the usual sequelae of psychologisation nevertheless

7 The 'big society' is the flagship phrase of the new conservativedominated British coalition government (from May 2010) where it seems that rather being a big society, rather society is composed of big individuals - as indicated by the rapid privatisation of major government functions underway to be run instead by big businesses. 
appear - in the form of stripping the context away from the subject with all the usual risks of victimblaming. Having been left out of the picture - state support and intervention can then re-enter only as and how they like. This is alongside the classic hallmarks of the workings of a 'risk society' - with individuals bearing the mark of 'risk', not only now on their bodies but also in their minds, giving rise to the societal imperatives to assess and clean up errant interiorities - cue the rise (and rise) of cognitive behavioural and 'mindfulness' therapies.

I note such developments as a cautionary tale, which link back to psychoanalysis as well as psychology. Right now, the question of the role of psychoanalysis as a conceptual model (to connect the world of feeling and of fact, agency and structure etc.) and as technology (to investigate this) is polarising this new community of self-styled critical academics. Is psychoanalysis necessary to, or even necessarily a critical resource for, this new hybrid discipline? (Burman, 2008c; Frosh, 2010; Frosh \& Baraitser, 2008; Parker, 2008). While perhaps also a narcissism of minor differences, major political tensions are being played out through apparently conceptual or disciplinary commitments. For many former leftists and feminists, deeply affected by the failure of European supposedly communist states, psychoanalysis has come to replace rather than supplement their politics, with the project of political change through personal transformation seeming one of the only routes left open. Interestingly contestations over the claim to psychoanalysis in psychosocial studies also link to the question of whether other theories can work as conceptual resources for this new discipline (Brown \& Stenner, 2009).

\section{Neopositivism}

Perhaps I scarcely need to mention this third turn. The new era of global economic recession has followed swiftly a rise of fundamentalism in all modes of thinking - not only religious but also cultural and intellectual. Significantly this poses many problems for feminist movements and women's increasing economic and sexual liberties. In state policy do- mains there have been increasing moves away from methodological diversity and attentiveness to innovative research approaches back to a scientism that also mobilises the pseudo-democratic discourses of transparency and accountability (Maclure, 2005). Yet what is happening is that we are being made into more accountable subjects, who are increasingly surveyed - our movements and habits documented, recorded all the time - but with less and less attention to our actual subjectivities. It is in this sense that De Vos (in press) cogently argues that current governmental modes of psychologisation in fact evacuate, rather than prescribe, subjectivity. Policies evaluating state health and education systems - following the US models of 'No Child Left Behind' and more (we have our own versions of this in the UK with 'Every Child Matters') and various forms of 'managed care' have been defining ever more restrictively the forms of research and service evaluation that will be deemed acceptable, instilling norms of experimental random control and blind allocation to conditions as the only 'gold standard' that return us back to the first line of criticism of the application of scientific procedures to reflexive psychological subjects (Denzin, 2006). All this hardline thinking is of a piece with the revival of other hardwired analyses - of the neuro-evolutionary paradigm now sweeping through psychiatry, health, etc, and in which evolutionary psychology is flourishing.

The mapping of the human genome seemed to restore faith in the project of scientific, rational technological progress. But it won't be long before the far-fetched claims engendered will have to become tempered - for as we psychologists know only too well, any genotype can only realised within specific phenotypes which are contingent on a host of sociohistorical conditions... so the problems of nature and nurture that were hailed to be solved by such discoveries are merely restated anew but in so fascinating a guide as to be beguiling.

\section{Conclusion: Disciplines for and against psychology}

Consideration of these three turns, and their wider cultural-political conditions, enables us to recon- 
sider the role of psychology as a discipline and its role in responding to the demands of the times. It was the early psychologists of the twentieth century who responded to British government demands to invent testing as a way of sorting and classifying people for purposes as diverse as determining who was (in)educable, who was fit to fight colonial wars, and who was fit to work (Rose, 1985), thus paving the way for psychologists to serve and show their usefulness to the modern bourgeois state.

It is nevertheless important not to overstate the role of psychology. As one originator of the concept of the 'psy complex', David Ingleby, pointed out in an early critique: 'Psychologists claim to be social engineers, but turn out to be really maintenance men' (1972, p. 57). In a particularly relevant reflection, Nikolas Rose (1999) further notes that '... expertise is heterogeneous. Its characteristic style of activity is bricolage... only later is the attempt to ratify the coherence of this array of procedures and forms of thought, to formalize them as a certain 'specialism'... (ibid). This is what enables it to inform and colonize other disciplinary, professional and social practices in its "generosity" (p. 87). Rose emphasises psychology's disparate and responsive character - as confirming and consolidating received ideas and procedures, to give them spurious credibility, rather than offering any genuinely new or coherent model. It is in this sense that psychology is a recursive technology of subjectivity that confirms its own expertise; that is, enabling it to occupy the status of both commonsense and mystificatory jargon.

But, as indicated by the three examples with which I began, the relation to other disciplines is not simply one of mutual deference, nor of replacing the discipline of psychology with another - history or anthropology, for example. Cultural psychology has faced this conundrum for some time - it is not a question of 'going native' in another discipline, for (as I was indicating earlier in relation to Women's Studies) each discipline can reproduce the same set of problems (around epistemology and ontology, for example) in its own way. Hence doing a bit of cultural tourism in another discipline simply reiterates the dynamics of homogenising and es- sentialising multiple and diverse cultural practices that we know happens in the more physical travel variety. So I am not advocating replacing psychology with another discipline. Nor is it a matter of setting these disciplines alongside each other in separate (if uneasy) co-existence (as is the case in much 'multidisciplinary' practice) whereby prevailing power relations and hierarchies are simply reproduced (as where the psychiatrist is 'top dog' in any multidisciplinary mental health team, and the medical model prevails). Nor, it seems to me, can we imagine that we can dispense with disciplinary distinctions in some easy discourse of 'interdisciplinarity' - for this move is something that has to be built in a self-conscious way, and in a climate of mutual suspicion as well as respect. I have been suggesting that feminisms - with their hybrid epistemological and methodological commitments - may be especially suited to be a critical resource for mobilizing and evaluating knowledge claims across disciplines, and - better still - in connecting with practice.

In this paper I have applied a feminist critical focus to the questions of disciplines and made the case for feminist psychologists to also become antipsychologists as part of the move to critique contemporary modes of psychologisation as the instrumentalisation of emotions and the promotion of individual responses to structural and resource limitations of twenty first century neoliberal times. I suggested that feminists need to be antipsychologists in part because of the antifeminist turn that may be instituted precisely by the resistance to these new psychological regimes, also to demonstrate that although the emotional turn may use the discourse of femininity, it is far from feminist (and indeed often women have disappeared from it too). I then turned to consider how commonplace representations of psychological knowledge include both explicit and implicit gendered, raced and classed assumptions that have significant bearing on the formulation of normalised and pathologised subjects.

What feminist antipsychologists - as also psychologists - can do is to unravel such constellations of meanings, both conceptually and also by 
analysing the emotional dynamics they set in train, to better equip social and political analysis, critical intervention and activism. Of course feminism is not the only resource - it is perhaps merely indicative of other frameworks that combine a distinct theoretical perspective with a commitment to engagement and intervention in practice - such as is also the case with postcolonial, queer and disability theories and activism - that means that the critique can never rest at the level of theory alone.

This analysis is useful in the current context where the arena of critical psychology is increasingly gaining recognition, and has made substantial interventions in psychology and about psychology - including highlighting the origins and problems of the rational unitary subject of modern mainstream psychology (Henriques et al., 1984). It has both transitional and revolutionary elements (e.g. Parker, 2007) as well as inevitably risking recuperation as it gains more credibility. However, a particular benefit of claiming feminism as antipsychology is that it sidesteps the interminable preoccupations of critical psychologists about whether, how, or how much they are (or their work is) part of psychology. But it also mobilises the widest reaches of feminist inquiry and brings these to bear on more parochial psychological matters. In this regard, I would not want to colonise or limit feminist debates, in the sense of confining them merely to being antipsychology (perhaps they are also antisociology, for example?).

I will end by indicating some specific disciplinary implications. To psychologists, this paper has aimed to clarify how too easy slippage of this disciplinary discourse secures the interests of wider political agendas. To those who dismiss psychology, there are indications that not only psychology is complicit with and shaped by such agendas. Alternatively, to those (including psychologists) who overstate the importance of psychology, the analysis here suggests how malleable and slight are the psychological claims mobilised, despite (or rather precisely because of) their wide (trans)cultural reference and circulation. Finally, as a feminist antipsychological intervention, it is fitting to end by noting that particular challenges are posed by this account also for feminist approaches, in forging analyses that ward off either the absolute separation of, or the merging, of women's with other positions.

\section{References}

Ahmed, S. (2004). The Cultural Politics of Emotions. Edinburgh: Edinburgh University Press.

Alldred, P. \& Burman, E. (2005). Hearing and interpreting children's voices: Discourse analytic contributions. En S. Greene \& D. Hogan (Eds.), Researching children's experience: Approaches and methods (pp. 175-198). London: Sage.

Armistead, N. (Ed.). (1974). Reconstructing social psychology. Harmondsworth: Penguin.

Balagopalan, S. (2010). Rationalizing seclusion: A Preliminary analysis of a residential schooling scheme for poor girls in India. Feminist Theory, 11(3), 295-308.

Batliwala, S. \& Dhanraj, D. (2007). Gender myths that instrumentalize women: A view from the Indian frontline. En A. Cornwall, E. Harrison \& A. Whitehead (Eds.), Feminisms in development: Contradictions, contestations and challenges ( $\mathrm{pp}$. 21-34). London: Zed Press.

Batsleer, J., Burman, E., Chantler, K., Pantling, K., Smailes, S., McIntosh, S., et al. (2002). Domestic violence and minoritisation: Supporting women towards independence. Manchester: Manchester Metropolitan University, Women's Studies Research Centre.

Bhavnani, K. (Ed.). (2001). Feminism $8 \mathcal{6}$ 'Race'. Oxford: Oxford University Press.

Billig, M. (1995). Banal Nationalism. London/Thousand Oaks: Sage.

Brown, S. \& Stenner, P. (2009). Psychology without foundations: History, philosophy and psychosocial theory. London: Sage.

Buikema, R. \& Smelik, A. (Eds.). (1993). Women's studies and culture: A feminist introduction. London: Zed Press.

Burman, E. (Ed.). (1998). Deconstructing feminist psychology. London: Sage

Burman, E. (2004). Taking women's voices: The psychological politics of feminisation. Psychology of Women Section Review, 6(1), 3-21. 
Burman, E. (2006a). Emotions, reflexivity and feminised action research. Educational Action Research, 14(3), 315-332.

Burman, E. (2006b, March). Feminism(s) or feminisation? Between autonomous triumphalism and victimhood. Keynote talk, The Frailty of Social Relations Conference, Círculo de Bellas Artes, Madrid.

Burman, E. (1994/2008a). Deconstructing developmental psychology. London/New York: Brunner Routledge.

Burman, E. (2008b). Developments: Child, image, nation. London/New York: Brunner Routledge.

Burman, E. (2008c). Resisting the de-radicalization of psychosocial analyses. Psychoanalysis, Culture and Society, 13, 374-378.

Burman, E. (2009). Beyond emotional literacy in feminist and educational research. British Education Research Journal, 35(1), 137-156.

Burman, E. (2010). Between justice and pathologisation: Juxtapositions of epistemic and material violence in transnational migration and domestic violence research. In J. Schostak \& G. Schostak (Eds.), Researching violence, democracy and the rights of people (pp. 42-60). London: Routledge.

Burman, E., Aitken, G., Alldred, A., Allwood, R., Billington, T., Goldberg, B., et al. (1996). Psychology discourse practice: From regulation to resistance. London: Taylor \& Francis.

Burman, E., Alldred, P., Bewley, C., Goldberg, B., Heenan, C., Marks, D., et al. (1995). Challenging women: Psychology's exclusions, feminist possibilities, Buckingham: Open University Press.

Burman, E. \& Chantler, K. (2005). Domestic violence and minoritisation: Legal and policy barriers facing minoritised women leaving violent relationships. International Journal of Law and Psychiatry, 28(1), 59-74.

Burman, E. \& Chantler, K. (2009, April). Research and social policy: A forced marriage? Unpublished paper presented at Discourse, Power and Resistance Conference, Manchester Metropolitan University, Manchester, United Kingdom.

Burman, E., Chantler, K. \& Batsleer, J. (2002). Service responses to South Asian women who attempt suicide or self-harm. Critical Social Policy, 22(4), 641-669.
Burman, E., Gowrisunkur, J. \& Sangha, K. (1998). Conceptualising cultural and gendered identities in psychological therapies: Models and practices. European Journal of Psychotherapy, Health and Counselling, 1(2), 231-256.

Burman, E. \& Maclure, M. (in press). Deconstruction as a method of research. En B. Somekh \& C. Lewin (Eds.), Research methods in the social sciences (2nd. ed.). London: Sage.

Burman, E. \& Parker, I. (Eds.). (1993). Discourse analytic research. London: Routledge. Available on www. discourseunit.com

Burman, E., Smailes, S. \& Chantler, K. (2004). "Culture" as a barrier to domestic violence services for minoritised women. Critical Social Policy, 24(3), $358-384$

Burman, E., Walker, K. \& Gowrisunkur, J. (2003). Sanjhe Rang: Developing a community-based intercultural psychotherapy service. Journal of Social Work Practice, 17(1), 63-77.

Burman, E. \& Whelan, P. (in press). Problems in/of qualitative research. In P. Banister et al. (Eds.), Qualitative Methods in Psychology: A research guide ( $2^{\text {nd }}$ ed.). Buckingham: Open University Press.

Butler, J. (1993). Bodies that matter. New York: Routledge.

Chamberlain, K. (2000). Methodolatry and qualitative health research. Journal of Health Psychology, 5(3), 285-296.

Chantler, K. (2006). Independence, dependency and inter-dependence: Struggles and resistances of minoritised women within and on leaving violent relationships. Feminist Review, 82, 27-49.

Chantler, K., Gangoli, G. \& Hester, M. (2009). Forced marriage in the UK: Religious, cultural, economic or state violence? Critical Social Policy, 29(4), 587-612.

Chantler, K., Burman, E. \& Batsleer, J. (2003). South Asian women: Systematic inequalities in services around attempted suicide and self harm. European Journal of Social Work, 6(2), 34-48.

Chantler, K., Burman, E., Batsleer, J. \& Bashir, C. (2001). Attempted suicide and self harm - South Asian women. Manchester: Women's Studies Research Centre, MMU. 
Clarke, S. \& Hoggett, P. (2009). Researching beneath the surface: Psycho-social research methods in practice. London: Karnac.

Clough, P. (with Halley, J.). (Ed.). (2007). The affective turn: Theorizing the social. Durham/London: Duke University Press.

De Vos, J. (2009). Now that you know, how do you feel? The Milgram Experiment and psychologization. Annual Review of Critical Psychology, 7, 223-246.

De Vos, J. (in press). Psychologization or the discontents of psychoanalysis. The call upon psychoanalysis to enter the cultural and scientific debate. Psychoanalysis, Culture \& Society.

De Vos, J. \& Gordo Lopez, A. (Eds.). (2010). Psychologism, Psychologising and De-Psychologisation [Editorial]. Psychologisation under scrutiny [Special issue]. Annual Review of Critical Psychology, 8.

Denzin, N. (2006). Disciplining qualitative research. International Journal of Qualitative Studies in Education, 19(6), 769-782.

Elam, D. (1994) Feminism and deconstruction. London: Routledge.

Fairclough, N. (1989). Language and Power. London: Longman.

Fendler, L. (2001). Educating flexible souls: The construction of subjectivity through developmentality and interaction. In K. Hultqvist \& G. Dahlberg (Eds.), Governing the child in the new millenium (pp. 119-142). New York/London: RoutledgeFalmer.

Foucault, M. (1977). Revolutionary action: "Until now" (D. F. Bouchard \& S. Simon, Trads.). In D. F. Bouchard (Ed.), Language, counter-memory, practice: Selected essays and interviews (pp. 218-233). Ithaca: Cornell University Press.

Francis, B. \& Skelton, C. (2005). Reassessing Gender and Achievement. London: Psychology Press.

Frosh, S. (2010). Psychoanalysis outside the clinic: Interventions in psychosocial studies. London: Palgrave.

Frosh, S. \& Baraitser, L. (2008). Psychoanalysis and psychosocial studies. Psychoanalysis, Culture $\mathbb{E}$ Society, 13, 346-365.

Gangoli, G. \& Chantler, K. (2009). Protecting victims of forced marriage: Is age a protective factor? Feminist Legal Studies, 17, 267-288.

Goffman. E. (1979). Gender advertisements. Cambridge; MA: Harvard University Press.
Gordo Lopez, A. \& Burman, E. (2004). Emotional capital and information technologies in the changing rhetorics around children and childhoods. New Directions in Child Development, 105, 63-80.

Gowrisunkur, J., Burman, E. \& Walker, K. (2002). Working in the mother-tongue: First language provision and cultural matching in inter-cultural therapy. British Journal of Psychotherapy, 19(1), 45-58.

Guba, E. G. \& Lincoln, Y. S. (2005). Paradigmatic controversies, contradictions, and emerging influences. In N. K. Denzin \& Y. S. Lincoln (Eds.), The Sage handbook of qualitative research ( ${ }^{\text {rd }}$. ed., pp. 191-215). Thousand Oaks, CA: Sage.

Gupta, R. (Ed.). (2003). From homebreakers to jailbreakers: Southall Black Sisters. London: Zed Press.

Hanmer, J. \& Itzin, C. (Eds.). (2000). Home truths about domestic violence. London: Routledge.

Harding, S. (Ed.). (1990). Feminism \& methodology. Buckingham: Open University Press.

Henriques, J., Hollway, W., Urwin, C., Venn, C. \& Walkerdine, V. (1984). Changing the subject: Psychology, social regulation and subjectivity, London: Methuen.

Hollway, W. (1989). Subjectivity and method in psychology. London: Sage.

Ingleby, D. (1972). Ideology and the human sciences: Some comments on the role of reification in psychology and psychiatry. In T. Pateman (Ed.), Countercourse: A handbook for course criticism (pp. 51-81). Harmondsworth: Penguin.

Jackson, A. Y. \& Mazzei, L. A. (Eds.). (2009). Voice in qualitative inquiry: Challenging conventional, interpretive, and critical conceptions in qualitative research. London/New York: Routledge.

James, A. \& Prout, A. (Eds.). (1990). Constructing and reconstructing childhood. London: Falmer.

Jenks, C. (1996). Childhood. London: Routledge.

Kofsky Scholnick, E. (2000). Engendering development: Metaphors of change. In P. Miller \& E. Kofsky Scholnick (Eds.), Towards a feminist developmental psychology (pp. 11-28). New York/London: Routledge.

Kothari, U. (Ed.). (2005). A radical history of development studies. London: Zed Press.

Lather, P. (2006). Paradigm proliferation as a good thing to think with: Teaching research in education as a 
wild profusion. International Journal of Qualitative Studies in Education, 1(1), 35-57.

Lombardo, E. \& Verloo, M. (2009). Contentious citizenship: Feminist debates and practices and European challenges. Feminist Review, 92, 108-128.

Maclure, M. (2005). Clarity bordering on stupidity: Where the quality in systematic review? Journal of Educational Policy, 20(4), 393-416.

Michell, J. (1997). Quantitative science and the definition of measurement in psychology. British Journal of Psychology, 88(3), 355-383.

Michell, J. (2004). The place of qualitative research in psychology. Qualitative Research in Psychology, 1(4), 307-319.

Morini, C. (2007). The feminisation of labour in cognitive capitalism. Feminist Review, 8, 40-59.

Morss, J. (1996). Growing critical: Alternatives to developmental psychology. London: Routledge.

Nieuwenhuys, O. (2007). Embedding the global womb: Global child labour and the new policy agenda. Children's Geographies, 5(1-2), 149-163.

Orbach, S. (2001). Towards emotional literacy. London: Virago.

Oakley, A. (1981). Interviewing women: A contradiction in terms. En H. Roberts (Ed.), Doing feminist research (pp. 30-61). London: Routledge \& Kegan Paul.

Parker, I. (1992). Discourse dynamics. London: Sage.

Parker, I. (2007). Revolution in psychology: From alienation to emancipation. London: Pluto Press.

Parker, I. (2008). Foucault, psychology and the analytics of power. Psychoanalysis, Culture $\mathcal{E}$ Society, 13, 217-220.

Parker, I. \& The Bolton Discourse Network. (1999). Critical textwork: An introduction to varieties of discourse analysis. Buckingham: Open University Press.

Parker, I. \& Shotter, J. (Eds.). (1990). Deconstructing social psychology. London/New York: Routledge.

Pearson, R. (2007). Reassessing paid work and women's empowerment: Lessons from the global economy. Ïn A. Cornwall, E. Harrison \& A. Whitehead (Eds.), Feminisms in development: Contradictions, contestations and challenges (pp. 201-213). London: Zed Press.
Phoenix, A. (1987). Theories of gender and black families. In G. Weiner \& M. Arnot (Eds.), Gender under scrutiny (pp. 50-61). Basingstoke: Hutchinson.

Popkewitz, K. \& Bloch, M. (2001). Administering freedom: A history of the present - rescuing the parent to rescue the child for society. In K. Hultqvist \& G. Dahlberg (Eds.), Governing the child in the new millennium (pp. 85-118). New York/London: RoutledgeFalmer.

Richardson, D. \& Robinson, V. (Eds.). (1993). Introducing women's studies. London: Macmillan.

Richards, G. (1996). Putting psychology in its place. London: Routledge.

Riley, D. (1983). War in the nursery: Theories of mother and child. London: Virago.

Riley, D. (1988). Am I that name? Feminism and the category 'woman' in history. London: Macmillan.

Rose, N. (1985). The psychological complex: Psychology, politics and society in England 1869-1939. London: Routledge \& Kegan Paul.

Rose, N. (1989). Governing the Soul: the shaping of the private self ( $1^{\text {st }}$. ed.). London: Routledge.

Rose, N. (1999). Governing the Soul: the shaping of the private self $\left(2^{\text {nd }}\right.$. ed.). London: Free Associations Books.

Siddiqui, N., Ismail, S. \& Allen, M. (2008). Safe to return? Pakistani women, domestic violence and access to refugee protection: A report of a transnational research project conducted in the UK and Pakistan. Manchester: South Manchester Law Centre/Manchester Metropolitan University.

Smart, C. \& Sevenhuijsen, S. (Eds.). (1989). Child custody and the politics of gender. London: Routledge.

Squire, C. (1990). Feminism as antipsychology. In E. Burman (Ed.), Feminists and psychological practice (pp. 76-88). London: Sage. Available on www. discourseunit.com

Spelman, E. (1990). Inessential Woman: Problems of exclusion in feminist thought. London: The Women's Press.

Stanley, L. (Ed.). (1990). Feminist Praxis. London: Routledge.

Stanley, L. \& Wise, S. (1983). Breaking out: Feminist consciousness and feminist research. London: Routledge $\&$ Kegan Paul. 
Staples, D. (2007). Women's work and the ambivalent gift of entropy. In P. Clough (with J. Halley) (Eds.), The affective turn: Theorizing the social (pp. 119. 150). Durham/London: Duke University Press.

Tamboukou, M. (2003). Interrogating the "emotional turn": Making connections with Foucault and Deleuze. European Journal of Psychotherapy, Counselling and Health, 6(3), 209-224.
Timimi, S. (2005). Naughty boys: Antisocial behaviour, $\mathrm{ADHD}$ and the role of culture. London: Palgrave.

Trendler, G. (2009). Measurement theory, psychology and the revolution that cannot happen. Theory \& Psychology, 19(5), 579-599.

Walkerdine, V. (1988). The mastery of reason. London: Routledge.

Walkerdine, V. \& The Girls and Mathematics Unit. (1990). Counting Girls Out. London: Sage. 